\title{
CONFIRMACION DE FUEROS A LA CIUDAD Y REINO DE MURCIA POR JAIME II DE ARAGON (1296-1304)
} Anexo documental inédito

Por

JUAN-MANUEL DEL ESTAL 
El objeto de este trabajo es la publicación del traslado notarial de una carta de Jaime II al concejo de Murcia, hasta la fecha inédita, en confirmación de los fueros y buenos usos de que habían disfrutado bajo la hegemonía castellana, hasta el momento de su conquista por Aragón, el 19 de mayo de 1296 (1).

Se trata de la contestación afirmativa del monarca a la demanda por parte del concejo de Murcia de una serie de capítulos o postulados, catorce en total, concernientes a los fueros y libertades que disfrutaban sus vecinos, bajo el régimen castellano anterior (1243-1296), solicitando de los mismos su reconocimiento y nueva confirmación.

Por presentar aquí su transcripción completa, más su versión castellana y correspondiente comentario resumido, renunciamos ahora a analizar su contenido.

(1) Tras un asedio de siete días, 12-18 mayo 1296, ocupó Jaime II la capital del Reino, pudiendo al día siguiente datar ya su correspondencia de este modo, bien expresivo al respecto: $\alpha$ Scrita en Murcia XIX dias anats del mes de Maig. En lany M. CC. XC. VIs, vid. ACA, Reg. de Regno Murcie, 340, fol. 74 r. Mayor información sobre esta eférides del monarca aragonés v. ESTAL, J. M. del: aDos cartas-privilegio inéditas de Alfonso $X$ el Sabio y Jaime II de Aragón, respectivamente a favor de la villa de Orihuela, años 1281 y 1296», ITEM, 3, Alicante, 1978, pp. 73-86, y particularmente las notas 15 y 21 . 
Queremos subrayar tan sólo algunos puntos que merecen destacarse de modo particular. Figuran entre otros la firme voluntad del monarca de evitar la menor discriminación étnica o religiosa en la población del Reino de Murcia, mayoritariamente sarracena y en parte judía (v. números 7,8 ), consciente del interés e importancia que todo ello significaba para el bienestar de sus gentes y seguridad del Reino (Apéndice documental: IV, V, VI, VIII, IX, X, XI, XII, XXIIII, XXIV, XXV y XXVIII) acabado de conquistar; su resolución a no tolerar ni permitir por ningún medio la partición, enajenación, separación o escisión de este reino de la Corona (núm. 1); obligación de reconocerlo en el espacio de treinta días como a su rey y señor natural (núm. 2; Apéndice XIII y XIV); confiscación de los bienes y heredamientos a los rebeldes (números 8 y 12; Apéndice: VII, y XVII, sobre todo); la partición de las tierras y demás bienes inmuebles de Murcia, entre sus fieles y más adeptos (núms. 3, 8 y 12 sobre todo; Apéndice: I, VI, VII, XV, XVI, XX); concesión de amplias libertades y franquicias por todas las tierras del Reino, disfrutando de los fueros otorgados por Alfonso $\mathrm{X}$ el Sabio y sus sucesores (núm. 2; Apén.: II, V, VI, X, XXI, XXII, XXVIII y XXIX); confirmación de los heredamientos y donaciones efectuados por sus antecesores castellanos (núms. 2, 3, 5, 8 y 12, sobre todo; Apénd.: I, VI, $\mathrm{XV}, \mathrm{XVI}, \mathrm{XX}, \mathrm{XXIII}$ ); indulto general de toda infracción perpetrada anteriormente, en guerra, tregua o paz, siempre que se le acate por sen̄or (núm. 4; Apénd.: XIII, XIV, XVII); franquicia total a los vecinos de Murcia por todas las tierras del Reino y seguridad para las personas y cosas por doquier en todo el ámbito del mismo (núms. $6,7,9,12$ ) y exención de los derechos de portazgo para el pan, vino y demás productos que deseen llevar de una parte a otra del Reino, salvo a tierras enemigas o de proluctos vedados (13; Apéndice: IV, VIII, IX, X, XI, XX, XXI, XXII, XXIII, .XXVIII y XXIX); libre opción a reconncerlo en el espacio de treinta dias como propio soberano y señor suyo natural o bien rehusarlo en el espacio predicho, abandonando sus bienes y el lugar, pudiendo llevar consigo el ajuar que les pluguiere (núm. 8; Apéndice: XIII, XIV y XVII); facultad de redactar las actas judiciales y demás escrituras públicas en lengua vulgar en vías de su mayor inteligibi. 
lidad por la masa de vecinos (núm. 11; Apéndice: $\mathrm{XX}$ ); prohibición de gravar a los vecinos contra los fueros y costumbres del Reino (Apéndice: XXVI); licencia a reembolsar la suma de los diez mil sueldos, entregados al adelantado del Reino de Murcia por Castilla, Juan Sánchez de Ayala, para la reparación de las murallas de la ciudad, a base ahora de retener la parte correspondiente de las rentas municipales, de manera especial, las peytas serracenas (núm. 14; Apéndice: III); y, por último, facultad de servirse de los fueros castellanos, otorgados a la ciudad y Reino de Murcia, por Alfonso X el Sabio, y dos sucesores: Sancho IV y Fernando IV, bajo la precedente hegemonía castellana (número 2), hasta la confección y promulgación del Nuevo Fuero de Murcia (Apéndice: XVIII), cuya compilación tenía encomendada Jaime II a los jurisperitos y legistas Martín de Dios, Juan Meyani, y el canónigo leridano, Raymundo Cabrera (Apéndice: XIX y XXVII), quienes, al cabo de un año, habian podido tener rematada felizmente su obra, en un volumen dividido en cuatro libros, que Jaime II sancionó formalmente para todo el Reino de Murcia, el 25 de octubre de 1297. A partir de esta fecha, no habría otra norma jurídica a seguir que ésta ,tanto dentro como fuera de los tribunales, debiendo aplicarse graves penas fiscales y calonias a los infractores (Apéndice: XXVII). Disponia asi mismo el monarca que, a efectos de divulgar mejor su conocimiento y aplicación del mismo, en todos los lugares del Reino de Murcia, se hiciesen distribuir copias fehacientes en número abundante guardando el original en el archivo de la ciudad (ibid.).

Con todo ello, demostraba Jaime II, en modo elocuente, el celo desplegado en asegurar las tierras y gentes del Reino de Murcia, que acababa de incorporar a su Corona, facilitándoles la Carta Magna por la que habrian de gobernarse a su gusto, cuidando de complacerles sobremanera, confirmando todos sus fueros y libertades, que disfrutaban de antiguo, sin la más mínima discriminación étnica o confesional de los mismos, siempre y cuando lo aceptaran todos plenamente como a su nuevo soberano y señor natural. 
Ofrecemos a continuación la referida carta de Jaime II, en confirmación de los fueros, libertades, buenos usos y propiedades de la ciudad y Reino de Murcia, seguida del Anexo documental ya expresado.

1296, agosto 29. Murcia.-Traslado notarial de una Carta de Jaime II de Aragón al Consell de Murcia, obra de Domingd del Soler, notario puiblico de aquella ciudad, en respuesta oficial a una serie de cuestiones o capitulos, catorce en total, formulados al monarca por aquel municipio, concernientes a los fueros y libertades, que disfrutaban sus vecinos, bajo el régimen castellano anterior (1243-1296), y de los que solicitaban su reconocimiento y nueva ratificación, con extensión por un igual a todos sus moradores, ya fueran cristianos, moros o judios, sin la más minima discriminación, asi étnica como confesional. Los términos de esta carta son los mismos de la que le dirigiera el Consell, retomados ahora por Jaime II, con la expresión de su beneplácito y confirmación, en términos de un simple "E plau al Sennor Rey", salvo los casos que precisaban de rectificación, alguna reserva por su parte o concreción mayor. La fecha de la misma es posterior al 19 de mayo de 1296, por haber conquistado aquel dia la ciudad de Murcia.

A.C.A., Cartas Reales Dipl., Jaime II, Caj. 2, núm. 289. Inédita. A efectos de mayor claridad dividimos los 14 capítulos en otros tantos apartados y correspondiente separación.

Aquest aço es treslat de una Carta en que son escrits los Capitols de les graçies e de las merçess que el molt alt e molt noble Seynnor don Jayme por la graçia de deu Rey/ de Arago, de Mayorcas etc. al Consell de Murçia, segons que a fet scriure, la qual es sagellada ab lo son segell, etc./.

Aquestes son les graçieas e merçess quel Consell de Murçia demana al Sennyor Rey/.

244 
1. Primerament que en negun temps nols partira de la sua Corona ni del seu Sennoryu per neguna raho/.

E plau al Sennyor Rey e otorgaho/.

2. Item quels confferm los furs e Priuilegis e Franquesses e Libertats e merçess e honrres e bons uses que an del Rey Alffonso, que parays aia, e del altres que puis/del regnaren en Castella/.

E plau al Sennyor Rey/.

3. Item quels confferm la partiçio que fo feyta de Murçia e las donaçions en general e en espeçial, axi com cascunes cosas (?) de cor. poral possessio/.

E plau al Sennyor Rey, salu dret dun Rey al altre/.

4. Item que quando tota questio o demanda que ell (?) poguess fer contra alguns de qualque raho o malefiçi, que aguessen fet en la sua terra o en terra de Murçia e/ tota altra justiçia e pesquises e justificaçions de qualque raho sien tro al dia duy.

E lo Sennyor Rey o perdona en quant en Consell et tot ço que feyt sia entro/ el dia de huy, sia fet en pau o en guerra o en treua, mas si a algun hom desta terra aujen respres en pau o en treua, quels en façen dret/.

5. Item a tots les persons que son feyts axi duneys contra daltres coses ab cartes dels reys o dels adelantats que sien (borrado: seguets?)/.

E plau al Sennyor Rey/.

6. Item que tots los veys de Murçia sien franchs generalment per tot 
lo seu Sennyorju per mar e per terra, axi. en ço que huy a, com daquauant aura/.

E plau al Sennyor Rey/.

7. Item quels Jueus, els Moros sien salues persones ells e tot lo seu/. E plau al Sennyor Rey/.

8. Item que tots aquells que en aquesta auinença ne uollrran esser, que pro (? puede) quasqum anar salus ab tot lur moble. $\mathrm{E}$ si dins $\mathrm{XXX}$ dies uolrran tornar a la merçe del Rey, que no/ perden res de lur. E si lur (borrado: res fuese tolta?) ab ells, que romangan salu ab lur dret e que non minus sien entesses Jueus (Moros) e christians/, et si alguns son fora de la terra, al temps dato e dins $\mathrm{XXX}$ dics, pusque auran jurat al Sennyor Rey, uolrran uenir a merçe del Rey, que non perden lo seu/.

E plau al Sennyor del dret que huy y han/.

9. Item que tots los uehins de Murçia, que alguna cosa agen en qualque lugar del Regne, quels sia salu/.

E plau al Sennyor Rey/.

10. Item que tots los plets que son determenats e passats en cosa jutgada, quant per Juy o per cartes dels Reys, que no pusquen esser altra uegada retrotrats/.

E plau al Sennyor Rey/.

11. Item que tots les cartes publiques e les altres escriptures del plets ques façan en uulgar per la part que les gens plus clarament o entenen/.

E plau al Sennyor Rey/. 
12. Item que (borrado: confferm?) totes quantes donaçions ell auia fets e atorgades a alguns de cases o de heretaments o de rendes o de qualsque altres cosas dels/ uehins de Murçia e quels o confferm, axi com cascunes an possesio ab cartes del Rey o de altra manera/.

E atorgao lo sennyor Rey leuar/ aquells que dintre los XXX dies nol auran regonegut per Sennyor/.

13. Sennyor, per que entenem que es uostre seruj e de la terra, clamam uos merçe que puscam traure del Regne pan e uin et tots altres uiandes franques et quietes/ a portar en totes partes, salu en terra dels uostres enemics/.

E plau al Sennyor Rey. Exceptat com lo sennyor rey fees uet general per tot/.

14. E atrossi, Sennyor, quens façats merçe en lexar nos pendre les rendes del Regne de Murçia tro que aiam pagats diez mill solids quel Consell a manleuats per adobar/ los murs e les torres de la Vila (de Murcia) e que prestaren a Johan Sanchez (de Ayala), e als castellans sobre estes rendes, les quales els tenjen e prenjen per manament/ e Cartes del Rey o quens hi façats aquella ajuda que tingats per be/.

E daquest Capitol parlara en Bernat de Sarria ab all/.

(Y prosigue el escatocolo final del Traslado notarial que presentamos):

Sennyal (signo notarial) de mj Domingo del Ssoler, notarj publich de Murçia, que aquest treslat escriure fiu e comprous con el padron, veynt e noue dies de Agost/, era de mill e CCC e XXXIIII ans/ (año 1296). 


\section{Versión de la Carta de Jaime II y comentario histórico}

Traslado de la Carta que contiene los capítulos y gracias y mercedes que el muy eximio y noble señor don Jaime, por la gracia de Dios rey de Aragón, de Mallorcas, etc., otorgó al Consell de Murcia, y que está sellada con su sello propio.

Estas son las gracias y mercedes que el concejo de la ciudad de Murcia suplicó del Señor Rey:

1. En primer lugar, que nunca los separe de la Corona ni de su soberanía por ningún motivo.

(Se ruega al monarca Jaime II que la incorporación que acaba de efectuar de las tierras del Reino de Murcia, conquistadas hasta la fecha a Castilla, desde mediados de abril de 1296, que no torne a separarlas de nuevo y que jamás permita su clivisión o enajenación, de acuerdo con la promesa jurada a las villas de Orihuela y Alicante, 11 mayo 1296, donde se obligaba «quod nunquam casu aliquo separabimus... nec separari faciemus aut permittemus a Corona Regni Aragonum... et quod nullam donationem, venditionem, permutationem seu concambium vel altenationem inde faciemus, consentiemus seu etiam permittemus.... (2), legislando ahora otro tanto a favor de la ciudad de Murcia). Y se lo otorgó complacido el Rey.

2. Que les confirmemos también los fueros, privilegios, franquicias, libertades, mercedes, honores y buenos usos que recibieron de $\mathrm{Al}-$ fonso $\mathrm{X}$ el Sabio, que Dios tenga en el paraíso y de los que reinaron después de él en Castilla.

(2) Véanse las Cartas respectivas de Jaime II a las villas de Orihuela y Alicante en EstaL, J. M. del: «Fuero de adscripción de las villas de Orihuela y Alicante por Jaime II a la Corona de Aragóns, Miscelánea Medieval Murciana, V, 1980, pp. 31-34. 
Y accedió a ello complacido el señor rey.

(Aquí procedió Jaime II de igual modo a como lo hiciera con otras villas del Reino de Murcia, tras su conquista, como con Orihuela, por ejemplo (número del Apéndice, II), Mula (Apéndice, XXII y XXIII) y Cartagena (Apéndice, XX y XXI) otorgando a todas la confirmación de los privilegios emanados por sus antecesores castellanos, a raíz de su incorporación a Castilla por Alfonso el Sabio el año 1243.

3. Que les confirmemos asimismo la partición efectuada anteriormente de la ciudad de Murcia y las donaciones de carácter general y particular, así como de las demás cosas de que tomaron posesión.

Y plugo otorgarlo al señor rey, dejando a salvo sus derechos reales. (Se ruega a Jaime II la confirmación de las particiones y heredamientos efectuados por el Rey Sabio y sus sucesores en la ciudad y Reino de Murcia, accediendo a todo ello complacido (Apéndice: I, VI, VII, XV, XVI y XX).

4. Que toda demanda o acción judicial que pueda mover el Consell contra alguien, por razón de alguna infracción o maleficio, perpetrado dentro del municipio o tierras murcianas, hasta el día de la fecha, que se les indique el procedimiento a que habrán de ajustarse o bien no tenerlo en cuenta.

$\mathrm{Y}$ el señor rey otorgó indulto general a cuantos vecinos de Murcia pudieran ser encausados por actos realizados con anterioridad, ya fuera en tiempos de guerra, tregua o paz, hasta el día presente, debiendo devolver sus derechos, si a alguien se le hubiesen arreba. tado.

(Jaime II accedió gustoso a tal demanda de indulgencia, perdonan- 
do a todos los vecinos de Murcia su pasado, siempre y cuando acatasen su nueva soberanía y lo tuviesen por su rey y señor natural, confirmándole agradecido sus derechos y posesiones (Apéndice: I, VI, XIII, XIV, XV, XVI, XX y XXIII), exceptuando de su perdón a los rebeldes, que lo rechazaban, procediendo inflexible a la confiscación de sus haciendas y bienes (Apéndice, XVII), como ocurriera, entre tantos castellanos, a los nobles García Ordónez y García Meléndez, entre otros (Apéndice, VII).

5. Item que a todos a quienes han sido otorgados bienes entre sí o por cartas reales o bien de los adelantados, que obtengan su confirmación. Y plugo otorgarlo al señor rey.

(Los ejemplos son muchos y remitimos a los siguientes, Apéndice: I, VI, XV, XVI, XX y XXIII, de por sí asaz elocuentes al respecto). 6. Item que se otorgue a todos los vecinos de Murcia el fuero de franquicia por todas las tierras del Reino, tanto sobre las conquistadas hasta la fecha, como sobre las que ocupe con posterioridad.

Y plugo al señor rey.

(Se pide al monarca la confirmación del fuero de franquicia a favor de los moradores de Murcia, para que puedan transitar con sus productos y mercaderías por todo el Reino, con entera libertad y seguridad, así sobre las tierras ya conquistadas, como las villas de Alicante, Orihuela, Mula, Cartagena, Crevillente, Guardamar, Petrel, Villena, Biar y Murcia, como sobre aquellas otras más meridionales del mismo, como Lorca, por ejemplo, que no sería sometida hasta finales del 1300 (Apéndice, IX, XXII, XXVIII y XXIX).

7. Item que los Judíos y Moros disfruten de seguridad en sus personas y bienes por todas las tierras del Reino.

Y plugo al señor rey. 
(Consciente cl Consell de Murcia de la elevada cifra de sarracenos y judios, que integraban la comunidad o universidad municipal murciana, suplicó a Jaime II, en interés del mayor beneficio co. munal, la confirmación de todas sus libertades y fueros, para sus respectivas aljamas, seguros de que tales medidas de tutela y singular protección contribuirían al desarrollo de su mayor común bienestar social y económico, vid. Apéndice, IV, V, VI, VIII, IX, X, XI, XII, XXI, XXIII, XXIV, XXV y XXVIII).

8. Item que todos aquellos que no quieran seguir en nuestra aveniencia, que pueden irse libremente del Reino con sus bienes muebles y ajuar propio y que, si en el plazo de treinta días, resolvieren volver a nuestra merced y devoción, que no pierdan sus bienes raíces. Y si alguien, dentro del tiempo fijado, fuese despojado de su hacienda, sin esperar a que fuese transcurrido, que todo le sea devuelto, según derecho. $Y$ que tales actos de favor no se hagan extensivos en menor escala a sarracenos y judíos, que entre cristianos. Y si algunos se hallaren, dentro del plazo establecido, fuera del Reino, si se sometieren al rey de Aragón, como a su soberano y señor, antes de extinguirse el plazo fijado, que se le respeten todos sus bienes $y$ no pierdan derecho alguno.

Y plugo al señor rey reconocerle tales derechos.

(Jaime II fijó el plazo de un mes a los vecinos de Murcia, al igual que hiciera con los restantes moradores del Reino, para que aceptasen su soberania y lo acatasen como a su nuevo rey y señor, procediendo, en caso afirmativo, a la confirmación de sus propiedades y bienes, a título vitalicio y hereditario, y en caso negativo, a la confiscación global de los mismos, vid. Apéndice: XIII, XIV, I, VI, XV, XVI, XX, VII, XVII).

9. Item que disfruten los vecinos de Murcia de seguridad y franquicia en todas las tierras del Reino. 
Y plugo al señor rey otorgarlo.

(Reiteradamente encontramos confirmados estos extremos en números anteriores de esta Carta, a los que remitimos: $2,3,5,6$, con sus correspondientes documentos citados en el Apéndice, para cada uno de ellos, más los siguientes: IV, VIII, IX, X, XI, XIII, XIV, XVII, XX, XXI, XXII, XXIII, XXVIII y XXIX, imponiéndole determinadas restricciones, referentes a las cosas vedadas consabidas, como caballos y armas, etc., como lo expresará nuevamente Jaime II en el núm. 13).

10. Item que los pleitos que han sido fallados anteriormente por el juez o cartas reales, que no puedan ni deban ser revisados de nue. vo por reclamación o apelación contra la sentencia judicial.

Y plugo al señor rey acceder a ello.

(Con esta petición se proponia el Consell murciano recabar del monarca el indulto general sobre los contenciosos de la época pasada, bajo la hegemonía de Castilla, y Jaime II resolvió favorablemente, disponiendo que el pasado contumelioso se olvidara a efectos judiciales, siempre y cuando se le aceptase como a propio soberano y señor natural del Reino de Murcia, según quedó establecido ya anteriormente en el número 4, con las aclaraciones pertinentes).

11. Item que todas las actas judiciales y demás escrituras públicas de los pleitos se redacten en lengua vulgar al objeto de que las gentes las entiendan mejor.

$Y$ plugo al señor rey.

(Jaime II otorgó esta gracia complacido, consciente de que la redacción de las escrituras públicas en lengua vulgar contribuiría a su mayor comprensión y ejemplaridad creciente de tales testimonios escritos, vid. Apéndice, $\mathrm{X}$ ). 
12. Item que cuantas donaciones, heredamientos, casas, rentas y demás bienes ha entregado el Consell a sus vecinos, que obtengan la confirmación del monarca, cual si se tratara de una donación real.

Y el señor rey asintió afirmativamente a ello, exceptuando a aquellos, a tenor de la práctica seguida, que en el plazo de los treinta días otorgados por él para reconocerlo como su monarca y señor, lo habian rechazado.

(En este apartado se pide la confirmación real de los heredamientos efectuados por el propio Consell murciano, a lo que Jaime II accedió complacido, supeditando, no obstante, la confirmación a que lo acatasen como a su propio soberano y señor natural, vid. supra núms. 3 y 4, con sus correspondientes documentos del Apéndice, alli señalados).

13. Señor, por entender que ello ha de redundar en vuestro mayor servicio $y$ en el de vuestra tierra, os pedimos la merced de la franquicia del portazgo de pan, vino y otras viandas y cosas que precisamos, por todas las partes del Reino, al objeto de permitirnos transportarlas por doquier con libertad y seguridad plenas, a excepción de las tierras del enemigo.

Y plugo otorgarlo al señor rey, salvo aquellas cosas prohibidas por veto general de la Corona.

(Jaime II asintió favorablemente a la demanda formulada por el concejo de Murcia, autorizándoles a transitar libres y seguros con sus productos y mercaderías por todas las tierras del Reino, sin discriminación alguna de raza o religión, dejando siempre a salvo la obligación permanente de no extraer jamás determinados productos, denominados cosas vedadas, del ámbito del Reino a campo 
enemigo, vid. Apéndice: IV, VIII, IX, X, XI, XX, XXI, XXII, XXIII, XXVIII y XXIX).

14. Y, por último, señor, os rogamos la merced de permitirnos retener de las rentas percibidas la suma de diez mil sueldos, que hubo de recabar el Consell de Murcia para hacer frente a la reparación de las murallas y torreones de la ciudad, entregándolos al adelantado del Reino de Murcia por Castilla, Juan Sánchez de Ayala, y a otros oficiales castellanos, que le exigieron aquellas rentas en nombre del rey; o bien que vos nos ayudeis a amortizar aquella deuda de otro modo, el que estiméis más oportuno.

Y acerca de este asunto cambiará impresiones el monarca con su consejero real, Bernat de Sarriá.

(Por tratarse de un problema económico, de relevante importancia, prefirió Jaime II aplazar la respuesta, al objeto de consultarlo antes con su consejero real, quien abogaria por una de las soluciones más usuales en tales casos y que en efecto consistía en la retención de un montante de las rentas comunales, que le permitiese resarcir la suma adeudada. Tal es, por ejemplo, el cobro de las peytas sarracenas por el municipio de Orihuela para afrontar gastos de esa indole, vid. Apéndice, III).

A continuación ofrecemos la trancripción de 29 piezas documentales, salvo dos, todas inéditas, a las que anteponemos un breve regesto, resumen de su contenido, seguido de su referencia bibliográfica.

Las presentamos como un anticipo de la Colección de documentos inéditos, que preparamos sobre la Historia del Reino de Murcia, bajo la hegemonia de Aragón (1296-1304) y de las restantes tierras alicantinas - Procuración del Reino de Valencia ultra Sexonam, desde su anexión al mismo, primavera de 1296, hasta las postrimerias de la Casa de Aragón, con la muerte de Martín I el Humano, en 1410. Es una obra que abar. 
cará varios volúmenes, de los que el primero está ya dispuesto para la imprenta, con cerca de 400 documentos.

1. 1296, abril 30. Campamento ante Almoradi (Alicante).

Donación de Jaime II a su portero real, Bernat de Genebret.

2. 1296, mayo 11. Orihuela.

Fueros de Jaime II a la villa de Orihuela y Franquicias.

3. 1296, mayo 11. Orihuela.

Jaime II otorga a Orihuela el cobro de las peytas sarracenas para reconstrucción de las murallas.

4. 1296, mayo 19. Murcia.

Salvoconducto y Guia de Jaime II a los sarracenos de Alguazas.

5. 1296, mayo 20. Murcia.

Jaime II asegura a los moros del Reino de Murcia la libertad $y$ posesión de sus bienes si lo acatan por su señor natural.

6. 1296, mayo 24. Murcia.

Provisión real de Jaime II a favor del arráez de la Arrixaca de la ciudad de Murcia, Abenhayça.

7. 1296, mayo 28. Sitio de Mula.

Donación a Bonanato Mercerio en la ciudad de Murcia de un heredamiento confiscado a Garcia Ordónez y García Meléndez, rebeldes a la causa de Aragón.

8. 1296, junio 1. Alhama de Segura (Murcia).

Guía y salvoconducto a favor del judío ilicitano, Isaac Vidal. 
9. 1296, junio 3. Campamento ante el castillo de Lorca.

Guiage y salvoconducto de Jaime II a favor de los cristianos, judios y sarracenos de Cartagena.

10. 1296, junio 3. Sitio de Lorca.

Jaime Il a favor de la franquicia del jus hospitii de la aljama judia de Murcia, ya desde Alfonso $X$ el Sabio.

11. 1296, junio 5. Huerta de Lorca, ante el sitio de su castillo.

Guia y protección real de Jaime II a favor de los moros de Petrel.

12. 1296, junio 6. Huerta de Lorca.

Imposición a los deudores del judio catalán, Abraham, de restituirle todos los préstamos que le adeudan.

13. 1296, junio 15. Sitio de Elche.

Orden de Jaime II al Consell de Murcia de remitirle sus procuradores ante su presencia para que le presten homenaje, como a su señor natural, transcurrido ya el plazo otorgado de los treinta dias.

14. 1296, junio 16. Sitio de Elche.

Carta de Jaime II a su hermano, Jaime Pérez, Procurador General del Reino de Murcia, para que le remita los sindicos de la ciudad de Murcia ante el cerco de Elche, para que le presten el homenaje debido como a su nuevo señor y rey. 
15. 1296, junio 22. Sitio de Elche.

Donación por Jaime II a Generoso, de la Casa real, de ciertos heredamientos en la ciudad y término de Murcia.

16. 1296, junio 22. Sitio de Elche.

Orden de confección de escritura pública de los heredamientos precedentes al consejero real, Bernat de Sarria.

17. 1296, junio 29. Sitio de Elche.

Orden de Jaime II al bayle general del Reino de Murcia, Bernat Colomer, de enviarle la relación de vecinos que han rehusado su soberania, para proceder a la confiscación de sus bienes.

18. 1296, julio 3. Sitio de Elche.

Orden al justicia de Murcia, Pedro Jiménez de Spilonga, de servirse de los fueros otorgados por Alfonso $X$ el Sabio, en tanto se lleva a cabo la compilación del Fuero. de Murcia que los reemplace.

19. 1296, julio 3. Sitio de Elche.

Carta al jurisperito murciano Martín de Dios y al legista Juan Meeyani para que aceleren la compilación del Fuero de Murcia.

20. 1296, julio 11. Sitio de Elche.

Confirmación a Cartagena de heredamientos y casas donados 
con anterioridad por Alfonso el Sabio y demás reyes castellanos.

21. 1296, julio 15. Huerta de Lorca, ante su castillo.

Confirmación a los vecinos de Cartagena, tanto cristianos como judios y sarracenos, de sus antiguos fueros castellanos.

22. 1296, agosto 2. Murcia.

Concesión a los vecinos de Mula de franquicia de lezda y peaje por todas las tierra del Reino de Murcia.

23. 1296, agosto 2. Murcia.

Confirmación por Jaime II a los vecinos de Mula, cristianos, judios y sarracenos, de todos los fueros, donaciones, buenos usos y costumbres sancionados por los reyes castellanos precedentes, sin la menor discriminación de etnia o religion.

24. 1296, agosto 3. Murcia.

Orden al comendador santiagista, fray López Pays, de Caravaca, Cehegin y Bullas, de hacer restituir los bienes retenidos a los judios Yuzeff y Abolazar.

25. 1296, agosto 3. Murcia.

Orden al alguacil y alcaydes de Mula de obligar a la restitución de las cantidades adeudadas a los judios Moisés Yuzeff y Abolazat por ciertos vecinos de la villa, que rehusaban la devolución. 
26. 1296, agosto 8. Játiva.

Carta de Jaime II al alcayde de Cartagena prohibiéndole gravar fiscalmente a los vecinos de la ciudad, contra sus fueros $y$ costumbres.

27. 1297, octubre 25. Tarragona.

Jaime II aprueba y sanciona el Fuero de Murcia, compilado por el canónigo leridano, Raymundo Cabrera, y los juristas Martín de Dios y Juan Meeyani, en un volumen, dividido en cuatro libros, con vigencia exclusiva para la ciudad y todo el Reino de Murcia (v. núms. 18 y 19 anteriores).

28. 1298, febrero 9. Sitio de Alhama (Murcia).

Provisión de Jaime II a favor de los judios que se desplazan a Alicante para atender a faenas agrícolas, disponiendo que disfruten de idénticas franquicias que los restantes vecinos, ya sean cristianos o sarracenos.

29. 1301, enero 21. Valencia.

Estatuto de franquicia a favor de los vecinos de Orihuela para que puedan comerciar y transportar por todas las tierras de la Corona los productos y demás viandas que les pluguiere, salvo les coses vedades, que espectica expresamente; mas aquellas otras, que por circunstancias singulares de carestía $u$ otras razones, se prohibiese extraer del Reino de Valencia y Murcia, haciéndolas recaer dentro del veto.

1296, abril 30. Campamento junto Almoradí (Alicante). 
Provisión real de Jaime II a favor de su portero real, Bernat Genebret, para hacerle entrega de ciertas casas y heredamientos en la ciudad y término de Murcia, pertenecientes hasta la fecha a Fernando Pérez Cantador, mayordomo del adelantado de Castilla en el Reino de Murcia, Juan Sánchez de Ayala, pero que, por su actitud rebelde contra Aragón, le habian sido confiscados, $y$ donados ahora en titulo de propiedad al beneficiario referido, en remuneración a sus numerosos servicios a la Corona (A.C.A., Reg. 340, fol. 288r. Inédito).

Nouerint uniuersi quod Nos Jacobus dei gratia Rex Aragonum etc. Attendentes grata et accepta seruitia que uos/ fidelis portarius noster, Bernardus de Genebreto, Nobis exhibuistis et exhibetis. Jdcirco per Nos et successores nostros titulo/ pure et perfecte donationis concedimus uobis dicto Bernardo et uestris in perpetuum domos et hereditamentum, quas et quod Fferdinan/ dus Petri Cantador, maiordomus Johannis Sancij habebat in Murcia et termino suo, que ad Nos confiscata sunt propter/ rebellionem dicti Fferdinandi. Jta quod uos et uestri perpetuo habeatis, tenatis et possideatis predictas domos et hereditamentum/, cum introitibus et exitibus eorumdem et cum omnibus juribus et pertinentijs suis predictis, prout melius et plenius dici et intelligi/ potest ad uestrum uestrorumque saluamentum et bonum intellectum, ad dandum, uendendum et alienandum et ad omnes uestras/ uestrorumque uoluntates perpetuo inde faciendas. Concedentes uobis quod propria auctoritate possitis ingredi et aprehendere possessionem/ omnium predictorum que uobis damus per uos uel per procuratorem uestrum, quandocumque uolueritis et aprehensam retinere. Constituentes/ uos in hijs dominum et procuratorem ut it rem uestram propriam, ad faciendum inde uestre libitum uoluntatis. Retinemus tamen/ Nobis et nostris quod, si dictus Fferdinandus Petri faciebat uel facere tenebatur aliquod tributum seu seruitium pro predictis, que uobis damus/, quod uos et uestri faciatis et facere teneaminj Nobis et nostris seruitium seu tributum supradictum. Mandantes procuratoribus/. Justicie, bajulis et uniuersis alijs officialibus et subditis nostris, presentibus et fufuris, quod presentem donatio- 
nem et concessionem/ nostram firmam habeant et obseruent et faciant/ inuiolabiliter obseruarj et non contraueniant nec aliquem contrauenire/ permittant aliqua ratione/.

Datum in castris apud locum de Almoredino, pridie kalendas madij, anno domini millesimo ducentesimo nonagesimo/Sexto/.

Signum (signo real) Jacobi dei gratia Regis Aragonum etc./

Testes sunt Raymundus Fulchonis, vicecomes Cardone, Guillelmus de Angleraria, Sancius de Antilione, Luppetus Fferrandi de Luna, Jacobus de Xericha/ Signum (signo escribano curial) fuit clausum per Petrum de Letone/.

1296, mayo 11. Orihuela.

Privilegio de Jaime II por el que otorga a la villa de Orihuela la inmunidad y exención de toda suerte de impuestos reales, tanto marítimos como terrestres, en el comercio del trigo, del vino y de la sal, por todas las tierras y aguas del Reino (1) (A.C.A., Can. Reg. Grat. 194, fol. 238r-238v).

Ville D'Oriola.

Nouerint uniuersi quod nos Jacobus dei gratia etc. Volentes vos uniuersos et singulos homines/ Oriole et terminorum eiusdem presentes pariter et futuros gratijs et beneficijs prosequi et fauore per/ nos et omnes successores nostros enfranchimus ac franchos et liberos facimus et inmunes uos uni/ uersos et singulos homines Oriole et termino-

(1) No hay constancia de este privilegio en el Libro de Privilegios, 2588, del A. M. de Orihuela, ni en el Ms. 1368B, del A.H.N. 
rum eiusdem presentes pariter et futuri per omnia Regna nostra et/ loca alia terrarum et dominationis nostre, que hodie habemus et in antea adquisiuerimus domino concedente/ tam per terram tanquam per mare quam quotlibet aquam dulcem, ab omni lezda, pedagio, passatico, portatico/ et ab omni ribatico, penso et mensuratico, tam bladi quam vini et salis, quam alterius cuiuslibet mercature/ quas uendatis aliquatenus et uendatis (tachado, por repetirse el término) uel ematis, recipientes nos omnes et singulos nuncios et capitalarios/ uestros et res uestras, veniendo, stando et exeundo per uniuersa et singula Regna nostra et loca quecunque terrarum/ et dominationis nostre, sub nostra custodia et protectione et guidatico speciali et statuimus ergo precipientes/ firmiter et districte quod aliquis vicarius, baiulus, lezdarius, pedagiarius, portarius seu quis (?) predictorum uel/ mensuratorum aut aliquis noster officialis uel subditus presens siue futurus nec audeant neque possint recipere/, exigere uel accipere a uobis uel mercibus, aut rebus uestris predicta uel aliquid de predictis, nisi uos seu bona uestra/, ratione predictorum distringendo seu compellendo ullo modo. Mandantes firmiter et districter omnibus supradictis et/ singulis et nostris subditis uniuersis, tam presentibus quam futuris quod hanc franchitatem nostram ratam ac/firmam habeant et obseruent et faciant semper ab omnibus firmiter obseruarj et non contraueniant ullo modo/ nec aliquem contrauenire permittant aliqua ratione./ Datum Oriole, quinto Jdus Madij. anno domini millessimo ducentessimo/ nonagessimo sexto/.

Signum (signo real) Jacobi dei gratia Regis Aragonum etc./

Testes sunt G(uillelmus) de Angularia, Jacobus de Xericha/

R(aymundus) Fulchonis (vice comes Cardone), Santius de Antilione, Petrus Martini de Luna/. 


\section{III}

1296, mayo 11. Orihuela.

En premio a los servicios prestados a la Corona por la villa de Orihuela, Jaime II le otorga los fondos obtenidos por la recaudación del impuesto capital o pechos y peitas de los sarracenos alli residentes, con destino a la reconstrucción y conservación de las murallas y fortalezas de aquel concejo (1). (A.C.A., Canc. Reg. Grat. 194, fol. 239r).

Transcribimos este texto por ser el más primitivo y correcto. Ville D'Oriola.

Nouerint uniuersi quod nos Jacobus dei gratia etc. Affectantes muros, turres, fortitudines loci nostri d'Oriola/ reparari et etiam si necesse fuerit de nouo fieri in ea parte in qua necessarium fuerit, damus, concedimus/ in prepetuum pro reparatione et constructione murorum predictorum peytam quam sarraceni d'Oriola pro capitibus soluere, et dare/ tenentur et debent et sunt soluere et dare actenus assueti. Sub tali tamen coiditione quod per uniuersitatem hominum/dicti loci de Oriola elegantur annis singulis duo probis (sic) uirj qui recipiant pecuniam pruenturam etiam que iam recepi debet ac/ recepi consueuit ex peyta predicta et receptam con uertant in reparationem et constructionem murorum et turrium predictorum/ et ex jnde Compotum et rationem baiulo nostro generali Regem (sic, en lugar de Regni) Murcie seu ville d'Oriola predicte juxta nostre libi/tum uoluntatis reddere tenentur. Jn cuius rei testimonium presentem cartam nostram fieri fecimus et nostro si/ gillo appendicio sigillari. Data Oriole, quinto Jdus Madij, anno domini millessimo ducentessimo nonagessimo sexto/.

(1) Faltan las partes concluyentes del escatocolo normal de la cancillería aragonesa: la Aprecatio, la Recognitio y la Subscriptio final de los testigos y escribano curial. Transcribimos este texto por ser el más primitivo y correcto. 
1296, mayo 19. Murcia.

Salvaconducto y guiage de Jaime II a favor de los sarracenos de Alguazas, en el actual partido judicial de Mula, para que puedan desplazarse $y$ residir en cualquier lugar del Reino de Murcia con plena libertad y seguridad para sus personas $y$ bienes (A.C.A., Reg. 340, fol. 75r).

Nos en Jacme per la gracia de deu Rey d'Arago, de Maiorchas, de Valencia e de Murcia e Comte de Barcelona/ quiam e a sseguram tots los sarrayns e cascun daquels, so es a saber, de Alguastes (Alguazas) en vinent dels dits locs per/ raho de estar e a qui estant e encara les coses e ols bens daquels. Manam a tots los offiçials e sots mesos/ nostros que aquest guiatge nostro ferm aien o obseruen e no hi menguen contra en neguna manera, sis confien de la/ nostra gracia e amor/.

Data en Murcia, XIV kalendas Junij anno predicto/ (millesimo ducentesimo nonagesimo Sexto)/.

Guillelmus de Solanis mandato regio/ (1).

\section{V}

1296, mayo 20. Murcia.

Carta de Jaime II a todos los mudéjares del Reino de Murcia para asegurarles que, de acuerdo con las promesas de su

(1) Son numerosos los testimonios de Salvoconductos y guiages que poseemos, a favor de moros y judios, extendidos por Jaime II de Aragón, para servirse de la merced regia por todo el Reino de Murcia, extensiva a sus personas y merca. derfas que trasportasen consigo, en demostración elocuente de su benevolencia y simpatía hacia los mismos. 
arráez, Ahmad iln Muhammad ibn Hudayr o Mahomet Abinhudell, en romance, respetaría todos sus bienes, hacienda y personas, si lo reconocian como soberano del Reino de Mur. cia y lo aceptaban por su señor natural, comprometiéndose a cumplir todas las seguridades y garantías prometidas y a confirmarles todos sus derechos y costumbres tradicionales. (A.C.A., Canc. Reg. 340, fol. 76r). Publ.: Guichard, Un señor musulmán..., 2, pág. 72.

Don Jaymes etc. A todos los Moros del Regno nuestro de Murcia de qualesquier logares sean la sua gracia/ e bona voluntad. Fazemos vos saber que el fiel e amado nuestro Mahomet Abinhudell, arrays de Crivillen, nos/ rogo muyto que nos que deviessemos assegurarvos e vuestros bienes, e tornariades a vuestros logares e reconoçieredes/ nos por senyor e por rey del Regno de Murcia e seriedes en nuestra fieldat, e nos querientes vos amar/ assi, como los nuestros antecessores an amado los Moros, que eran dejus lur senyoria, avemos acomendado/ al dito arrays que el que vos assegure de part nuestra, vos viniendo a nuestra senyoria e reconoçiendo/ nos por senyor e rey del Regno de Murcia segunt que dito es, por que nos vos femos saber que aquel/ asseguramento que el dito arrays vos fara en esta rayyon (?) que lo avremos Nos por firme e lo ternemos/ e los observaremos e lo faremos tener e observar bien e complidament./

Dada en la ciudad de Murcia, veynt dias/ andados del mes de mayo, anno predicto/ (millesimo ducentesimo nonagesimo sexto).

Guillelmus de Solanis mandato regio/.

\section{VI}

1296, mayo 24. Murcia.

Provisión real de Jaime II a favor del arrdez de la Arrixaca 
de Murcia, Abenhayça, confirmándole el dominio de un hor. no $y$ ciertas casas dentro de la ciudad y seis fanegas de tierra de cultivo en su término, e imponiendo a sus oficiales el respeto absoluto de tales posesiones (A.C.A., Reg. 340, fols. $107 \mathrm{v}$ 108r).

Nouerint uniuersi quod nos Jacobus dei gratia etc. ad instantiam et supplicationem nobis pro parte dilecti et fidelis nostrj Arraayç Abenhyça, factam, laudamus, approbamus ac etiam confirmamus per Nos et nostros dicto Arrayç Abenhayça et suis perpetuo furnum/ et cassas (?) que habet et tenet in Rexacha Murcie et sex fannechatas terre quas habet et tenet in La Algolega, juxta Andreas (? borroso) et uer (... borrado) laudationem et confirmationem dicto Arrayç Abenhayça de predicto furno et de dictis sex/ fannechatis terre, sicut melius et plenius dici et intelligi potest ad suum bonum et sanum intellectum. Jta quod predicta habeat et/ teneat per se et suos, sicut habet et tenet. Mandantes procuratoribus, bajulis, justicijs, juratis et uniuersis alijs officialibus nostris/, presentibus et futuris, quod presentem laudationem, approbationem et confirmationem nostram firmam habeant et obseruent et faciant ab alijs/ inuiolabiliter obseruarj et non contraueniant nec aliquem contrauenire permittant aliqua ratione/.

Datum Murcie, nono kalendas Junij, anno domini/ millesimo ducentesimo nonagesimo sexto/.

Signum (signo real) Jacobi dei gratia regis etc./

Testes sunt Raymundus Fulchonis, uicecomes Cardone, Guillelmus de

Angleraria/, Jacobus Petri, Jacobus de Xericha, Sancius de Antilione/.

Fuit clasum per manum Guillemi de Solanis/ (1).

(1) Prosigue la actitud benevolente de Jaime II hacia la población mudéjar, consciente de que tal procedimiento es el mejor camino para asegurar y afianzar la conquista incipiente por aquellas fechas del Reino de Murcia, por constituir aquélla el núcleo demográfico primordial de éste. 


\section{VII}

1296, mayo 28. Sitio de Mula.

Donacion por Jaime II a Bonanato Mercerio de un heredamiento en la ciudad y término de Murcia, perteneciente a García Ordóñez, y de un albar, denominado Datzeneta, propiedad de García Meléndez, a quienes se lo habia confiscado el monarca por su actitud rebelde contra Aragón y entregado en pleno dominio al beneficiario referido, en remuneración a los muchos servicios prestados, con las obligaciones y servidumbres acostumbradas (A.C.A., Reg. 340, fol. 258v).

Jacobus dei gratia etc. Attendentes grata et accepta seruitia que uos Bonanatus Mercerij, ciuis Murcie, Nobis exhibuistis et exhibetis. Jdcirco/ per Nos et successores nostros et titulo pure et perfecte donationis concedimus uobis dicto Bonanato el uestris in perpetuum totum illud heredita/ mentum, quod Garcias Ordonyes habebat in ciuitate Murcie et termino suo et hereditamentum secanum Datçeneta, quod erat Garcie/ Melendis, que ad Nos confiscata sunt propter rebellionem dictorum Garcie Ordonyes et Garcie Melendis. Jta quod uos et uestri perpetuo/ habeatis, teneaatis et possideatis predicta hereditamenta, cum introitibus et exitibus eorundem et cum omnibus juribus et pertinentijs suis predictis/, prout melius et plenius dictus Garcias Ordonyes et Garcias Melendis habebant et tenebant. Hanc autem donationem et concessionem/ facimus uobis dicto Bonanato et uestris, sicut melius dici potest et intelligi ad uestrum uestrorumque saluamentum et bonum intellectum/, ad dandum, uendendum et alienandum et ad omnes uestras uestrorumque uoluntates perpetuo inde libere faciendas. Concedentes uobis quod/ propria auctoritate possitis ingredi et aprehendere possessionem omnium predictorum que uobis damus, per Vos uel per procuratorem uestrum, quandocumque/ uolueritis et aprehensam retinere. Constituendo uos in hijs dompnum ut in rem uestram propriam ad faciendum inde uestre libitum/uoluntatis. Retinemus tamen Nobis et nostris quod 
si dicti Garcias Ordonyes et Garcias Melendis ffaciebant uel facere tenebantur/, aliquod tributum seu seruitium pro predictis que uobis damus, quod uos et uestri faciatis et facere teneaminj Nobis et nostris tributum seu/ seruitium supradictum. Mandantes procuratoribus, Justicijs, Merinis, bajulis et alijs Officialibus et subditis nostris etc./.

Datum in obsidione de Mula, quinto kalendas Junij, anno domini millesimo ducentesimo nonagesimo Sexto/.

Signum (signo real) Jacobi dei gratia Regis Aragonum etc./

Testes sunt Jacobus Petri, Jacobus de Xerica, Raymundus Fulchonis, vicecomes Cardone/, Petrum Martini de Luna/ et Albertus de Mediona/.

\section{VIII}

1296, junio 1. Alhama (Murcia).

Carta de aseguramiento y guiage de Jaime II a favor del judio de Elche, Isaac Vidal, para que pueda trasladarse libremente a la ciudad de Murcia y afincarse en ella, con todos sus bienes, siempre y cuando permanezca bajo su vasallaje y soberania (A.C.A., Reg. 340, fol. 119r).

Nos Jacobus dei gratia Rex Aragonum etc. Guidamus et assecuramus et sub nostra protectione et guidatico speciali recipimus uos Isachum Vidal, judeum, nunc habitantem/ in loco de Eltx, in ueniendo ad Ciuitatem Murcie, cum omnibus rebus et bonis uestris ac ibidem stando sub fide et dominio nostro/, mandantes per presentem litteram nostram nobili et dilecto fratri nostro Jacobo Petri, Procuratori Regni Murcie et uniuersis alijs/ officialibus et subditis nostris, quod presens guidaticum nostrum et assecuramentum nostrum uobis obseruent et obseruari faciant et non/ contraueniant aliqua ratione/. 
Datum in Alhama, kalendas Junij, anno domini millesimo ducentesimo nomagesimo Sexto/.

IX

1296, junio 3. Campamento ante Castillo de Lorca.

Guiage y salvoconducto especial de Jaime II a favor de los vecinos de Cartagena, tanto cristianos como judios y mudéjares, para que gocen de franquicia y libertad de movimiento para sus personas y mercaderias por todas las tierras y aguas del Reino de Murcia, suspendiendo incluso toda acción judicial pendiente sobre los mismos, por actos y crimenes cometidos con anterioridad, bajo la hegemonia castellana (A.C.A., Reg. 340, fols. 283v-284r).

Nouerint uniuersi etc. Uolentes uos uniuersos et singulos homines Ciuitatis Cartagenensis, tam christianos/ scilicet quam judeos ac sarracenos prosequi gracijs et fauore, guidamus et assecuramus uos per uniuersa et/ singula loca terrarum et dominationis nostre, tam per terram quam per mare, seu quamlibet aquam dulcem. Etiam nichilominus/ et indulgemus uobis et uestris perpetuo omnem petitionem, questionem, inquisitionem et demandam/ et etiam omnem penam ciuilem et criminalem, quamquam uos seu aliquem uestrum facere, mouere seu infligere/ possemus occasione alicuius criminis seu maleficij per uos seu aliquem uestrum perpetrarj temporibus retroactis usque ad huc tempora in aliqua parte terrarum et dominationis nostre ac etiam in Regno nostro/ Murcie, qualibet ratione, siue factum, commissum aut perpetratum fuerit in pace uel treuga siue gratia/, in quantum uidelicet ad Nos spectat. Uerumtamen si aliquis ex uobis in pace uel treuga aliquid ceperitis alicui/ (... borrado) sibi exinde facere justitie complementum, secundum autem/ guidaticum et assecuramentum nostrum ac etiam remissionem et indulgentiam predictam facimus uobis et uestris/, prout (... borrado) 
melius dici et intelligi potest ad uestrum uestrorumque saluamentum et bonum ac sincerum intellectum. Mandantes uniuersis et singulis procuratoribus, bajulis, justicijs et alijs officialibus nostris/, quod predictum Guidaticum et assecuramentum nostrum ac etiam remissionem, indulgentiam predictas firma habeant et obseruent/ et faciant inuiolabiliter obseruarj et non contraueniant nec aliquem contrauenire permittant aliqua/ ratione.

Datum in castris in orta Lorche, tertio nonas Junij, anno predicto/ (millesimo ducentesimo nonagesimo Sexto) (1).

\section{$\mathbf{X}$}

1296, junio 3. Sitio de Lorca.

Carta de Jaime II a su hermano, Jaime Pérez, Procurador General del Reino de Murcia, ordenándole que respete la franquicia de hospedaje, otorgada por Alfonso $X$ el Sabio a la aljama judia de Murcia, liberándolos de la obligación del jus hospitii de miembros de la familia real, contra su voluntad. Fuero que, al decir de una representación de la misma, se ha visto quebrantado uiltimamente por alguno de su propia casa real, y él no puede tolerar tal infracción (A.C.A., Reg. 340, folio 119r).

Nos Jacobus etc. uiro nobili et dilecto fratri suo Jacobo Petri, Procuratori Regni Murcie Generali. Ex parte Aljame Judeorum/ Murcie fuit expositum coram nobis, quod ipsi habent priuilegium ab illustrissimo domino Alffonso, clare memorie Rege/ Castelle, in quo concessit eis per se et suos presentes et futuros, quod nullus de familia sua seu alio-

(1) Prosigue el acento indulgente de Jaime II hacia todo el pasado de sus nuevos súbditos, por criminal o litigioso que fuere, siempre que lo acaten por su nuevo soberano y señor, sin la más discriminación racial o confesional hacia los mismos. 
rum Regum/ successorum suorum hospitaretur in domibus ipsorum judeorum Murcie contra uoluntatem ipsorum. Et quod nunc aliqui de fa. milia nostra (tal vez su propio hermano, Jaime Pérez, etc.) hospitaretur, contra uoluntatem dictorum judeorum et tenorem dicti priuilegii, in eorum domibus supradictis. Quare uobis dicimus et/ mandamus quatenus, si uobis constiterit judeos habere dictum priuilegium, nec permitatis aliquem de familia nostra, contra tenorem/ dicti priuilegii hospitarj in eorum domibus supradictis/.

Datum in obsidione de Lorcha, tertio nonas junij/ anno predicto/ (millesimo ducentesimo nonagesimo Sexto) (1).

\section{XI}

1296, junio 5. Huerta de Lorca, ante los muros del castillo. Jaime II ordena a todos sus oficiales y hombres públicos que respeten las personas y bienes de los sarracenos de Petrel, por haberlos acogido bajo su real amparo y protección, en cuya virtud disfrutan de plena libertad de movimiento por to. das las tierras del Reino de Murcia, prohibiendo severamente cualquier agravio o lesión contra sus personas $y$ bienes. (A.C.A., Reg. 340, fol. 122r).

Uniuersis ad quos presentes peruenerint etc. Noueritis Nos guidasse et assecurasse ac sub nostra protectione et Guidatico speciali/ recepisse Sarracenos de Petrer et omnes res eorum per omnia loca dominij nostri, in ueniendo, stando ac etiam redeundo/. Jta quod nullus confidens de nostri gratia uel amor presumat in aliquo loco dominationis nostre dictos Sarracenos ac bona eorum/ capere, inuedere, indebite

(1) Una vez más constatamos la firme voluntad del monarca aragonés de protejer a los judios y moros residentes en su Reino de Murcia, recién conquistado parcialmente, consciente de la necesidad de tener a sus aljamas a favor suyo, máxime cuando la población residente en aquellas tierras era mayoritariamente hebrea o musulmana. 
agrauiare seu etiam molestare. Quare uobis dicimus et mandamus, quatenus dictis Sarracenis/ predictum guidaticum et assecuramentum obseruetis et contra ipsa non uoniatis nec aliquem contrauenire permittatis/ aliqua ratione/.

Datum ut supra/ (in Orta de Lorcha, nonas Junij, anno domini millesimo ducentessimo nonagesimo Sexto).

\section{XII}

1296, junio 6. Huerta de Lorca.

Disposición de Jaime II por la que ordena a todos sus altos funcionarios la inmediata restitución de las sumas adeudadas al judio catalán, Abbraham, por todos aquellos deudores que se beneficiaron un dia de sus préstamos a interés, mediante escrituras públicas o sin ellas, siempre y cuando les conste la verdad de tales reclamaciones, pues le es intolerable semejante burla de la justicia (A.C.A., Reg. 340, fol. 124v).

Jacobus dei gratia Rex Aragonum etc. Dilectis et fidelibus suis officialibus nostris ad quos presentes peruenerint etc. Cum/ Abraham catalanus judeus asserat sibi plures quantitates pecunie deberi per diuersas personas, tam cum instrumentis/, quam sine instrumentis, quas sibi maliciose ut asserit soluere contradicunt, et supplicauerit Nobis humiliter inde super/ predictis debitis ei soluendis prouidere de benignitate regia dignaremur. Jdcirco supplicatione ipsa benigne/ admissa, uobis dicimus et mandamus, quatenus unusquisque uestrum in jurisdictione uobis commissa, cohercitione debita/ et prout instrumentum fuerit compellatis ad requisitionem dicti Abrahe et uniuersos et singulos, quos uobis constitterit/ aliquid sibi deberi, ad satisfaciendum inde sibi uel faciendum justicie complementum, malicijs et diffugijs/ non admissis, taliter quod ob defectum justicie ad Nos iterato recurrere non cogantur/. 
Datum in Orta de Lorcha/, octauo Jdus Junij, anro domini millesimo ducentesimo nonagesimo Sexto/ (1).

\section{XIII}

1296, junio 15. Sitio de Elche.

Carta de Jaime II al Consell de Murcia notificándole que por cumplirse el plazo de los treinta dias, otorgado por él para prestarle homenaje como a su nuevo soberano y señor natural, el próximo martes, dia 19, deberán elegir los procuradores y sindicos que han de llevar a cabo en nombre suyo tal cometido y hacer que se vean con él ante el Sitio de Elche, en la fecha referida, ya que él no puede abandonar el cerco de la villa y les ordena que los hagan portadores de plenos poderes comunales, al objeto de que pueda resolver con ellos todos los asuntos pendientes, como el de liberar del juramen. to de vasallaje prestado por Bernat de Sarriá, en rehén del alcázar de Murcia. Y a continuación da el visto bueno a la lista nominal de procuradores murcianos que integraban la comisión municipal referida (A.C.A., Reg. 340, fol. 143v).

En Jacme per la gracia de deu Rey Daragon, de Mallorches, de Valencia etc. Als (... borroso) feels (... borroso) seus (... borroso) e amats seus, als prohomens e a tota/ la uniuersitat de la Ciudat de Murcia. Com lo terme dels treynta dias per Nos demanats e per Nos atorgats sien/ complit, on aquest dimars primer que ue, e Nos segons que uos sabets,

(1) Desde el cerco de Lorca emanó Jaime II esta disposición a favor del judío catalán referido, ordenando que se le hiciese justicia, sin distinción de raza ni credo, pues no podía permitir que algunos cristianos, amparados en el escudo de la religión del monarca y de la corona, se negaran a pagar las deudas contraídas a sus acreedores, si éstos eran judíos o mudéjares, por el simple hecho de no ser cristianos, porque actos de tal índole maliciosa y dilación del pago debido no pueden tolerarse en modo alguno. 
tingam assejat lo loc Deltç (Elche), del qual/ bonament partir no porem e axi nos personalment a la Ciutat damuntdita anar ades no poxam, reebudes estes letres ordenets e elegats legitimament uostres/ Sindichs e Procuradors los quals a Nos ab la carta del Sindicat trametats per fer a Nos per part de tota/ la uniuersitat damuntdita homenage e sagrament, axj com a Senyor e a Rey del Regne de Murcia, e les altres/ coses que sots a Nos tenguts de fer, segons les Conuinences e postures entre Nos e uos fetes, e/ encara per soltar en Bernat de Serria del homenage que fue a uos altres per lAlcaçar de Murcia (por su tenencia en rehén) que fu a el/ comanat per raho del espay dels dits XXX dies. En tal manera quels dits Sindichs e Procuradors uos tres/ agren plen poder de uos altres de fer e de complir totes les coses damuntdites, feens en guissa aquels/ dits Sindichs e Procuradors sien denant la nostra presentia al dit Setge Deltç, dimars damuntdit/. E tenim per be quels sindichs e procuradors damuntdits sien aquest dijus nomenats e somts ço/ es a ssaber en Guarner Portel, en Portel Portel, Pero de Castellis, Pero Pelatj, Berenguer de Clarmont/, Bernat de Clarmont, Pagren Rodrigueç, Bernat Ermengol, Johan de Metya, Garsia Aztorino, Pero Plorem/, Bernat Soltyma, Raymond Darbia, Bartholomeu Ferrj/, Pero Ximeneç de Spilonga, Pero Martineç Pinton e en Boaada/.

E si mes ne uolets elegir e establir/ aço posseram en uostra uolontat/. Datum al Setge De Eltç, diuendres, XV dies anats del mes de Jun. En el ayn/ de mil e doçcens nouanta e sseys/ (1).

\section{XIV}

1296, junio 16. Sitio de Elche.

(1) Se precisa aquí una vez más la fecha exacta de la conquista de la ciudad de Murcia, al señalar la fecha del plazo aludido del mes, que cumplía el 19 de junio, martes, justamente a los treinta dias de aquel 19 de mayo en que Jaime II entró en Murcia, tras varios días de asedio. Plazo por otra parte que el monarca aragonés solía dar a los moradores de todas las ciudades, villas y lugares que conquistaba en el Reino de Murcia, para que lo acatasen como a su monarca y 
Carta de Jaime II al Procurador General del Reino de Murcia, Jaime Pérez, hermano suyo, en la que le notifica el emplaza. miento de los treinta dias, fijados por él al Consell de Murcia, para que al término de los cuales, el martes inmediato siguiente, 19 de junio, comparezcan sus procuradores $y$ sindicos en su presencia, ante el cerco de Elche, para que en nombre del municipio le presten el homenaje debido, como a su nuevo soberano y señor natural. Y que el miércoles siguiente, dia 20 , se presente él en la villa de Orihuela para recibir en nombre suyo el castillo oriolano de manos de su alcayde, Pedro de Dios (A.C.A., Reg. 340, fol. 143r).

Nobili et dilecto fratri suo Jacobo Petri ac Procuratori in Regno Murcie. Recepimus litteras uestras per uos Nobis missas/ super terminis per Nos assignatis hominibus Murcie ac etiam Oriole et intelleximus ea que Nobis in ipsis litteris intimastis/, unde uobis respondendo significamus quod terminus per Nos assignatus probis hominibus et uniuersitati Murcie erit finitus/ die martis proxime uentura et terminum quem assignamus hominibus Oriole erit finitus die mercurij proxima/ subsequenti. Propter quod Nos per litteras nostras requirimus dictos homines Murcie ac etiam mandamus eisdem quod constituant/ in sindicis eorum certos homines ex ipsis, in dictis litteris nostris nominatis, qui ueniant ad Nos et faciant Nobis homagium et sacramentum et faciant et compleant Nobis nomine suo et uniuersitatis predicte ea que Nobis tenentur/ facere et complere. Quare uobis dicimus et mandamus, quatenus ordinetis et procuretis quod dicti probi homines ciuitatis Murcie constituan sindicos et procuratores eorum, illos quos duximus eligendos ut in litteris quas eis super/ hoc mittimus uidebitis continerj (1), et

señor natural, al objeto de que él pudiera proceder acto seguido a confirmarles sus franquicias y fueros primitivos. También registra un singular interés esta carta para la primitiva antroponimia murciana, con su listado de veinte nombres y apellidos.

(1) Alusión a la carta, remitida el día anterior al Consell de Murcia, al objeto de que eligieran los miembros que habían de integrar la comisión municipal, que tendría que verse con él, el 19 de junio, en el cerco de Elche, para prestarle el homenaje debido, y resolver otros asuntos pendientes. 
quod die mercurij proxime uentura sitis apud Oriolam recepturum pro parte/ nostra Castrum de Oriola a Petro de Deo, qui ipsum uobis nomine nostro tradet/.

Datum in obsidione Eltxij, decimo sexto/ kalendas Julij, anno domini millesimo ducentesimo nonagesimo Sexto/.

\section{XV}

1296, junio 22. Sitio de Elche.

Provisión real de Jaime II por la que otorga a Gennoro, de la Casa real, ciertas casas y heredamientos en la ciudad y término de Murcia, distribuidos estos últimos por tierras de regadio y de albar o secano, pertenecientes hasta la fecha a Pedro López de Argomedo, y en posesión actualmente de Juan Pérez de Valladolid y Juan Ibáñez, que las tenian en nombre de Gonzalo y su hija Garcia Colmelo, a quienes fueron confiscadas por su actitud de rebeldia contra Aragón, imponiendo a su nuevo propietario, como de costumbre, las obligaciones y servidumbres de sus antiguos dueños con la Corona (A.C.A., Reg. 340, fol. $183 \mathrm{r}$ y v).

Nouerint uniuersi quod Nos Jacobus etc. Attendentes grata seruitia per uos Gennorem de domo nostra/ Nobis exhibita, que dante domino exhibere poteritis in futurum per uos et successores uestros, damus et titulo perfecte et pure dominationis concedimus uobis Gennoris et uestris in perpetuum/ domos et hereditamenta quas et que Petrus Lupi Dargomedo quondam habebat/ in Ciuitate Murcie, tam in regadiuo quam in sicano, quas quidem domos et hereditamenta/ Johannes Petri de Valladolit et Johannes Juannys nunc tenebant pro Gondiçaluo/ (... borroso) et pro filia Garsie Colmelo, et ea omnia Nobis confiscata sunt propter/ rebellionem eorum. Jta quod uos et uestri in perpetuum habeatis, 
teneatis et possidea tis dictas domos/ et hereditamenta cum introitibus et exitibus eorumdem et cum omnibus juribus et pertinentijs/ suis prout melius et plenius dictus Petrus Lupi Dargomedo et omnes alij predicti predictas domos/et hereditamentum habuerunt, tenuerunt et possiderunt. Hanc autem donationem et concessionem facimus/ uobis dicto Gennerosis (sic) et uestris perpetuo, sicut melius dici et intelligi potest etc. ad dandum, uendendum/ et alienandum et ad omnes uestras uestrorumque uoluntates perpetuo inde libere faciendas et concedendas/. jta quod uestra propria auctoritate possitis ingredi et aprehendere possessionem domorum predictorum et hereditamenti predicti/, tam per uos quam per procuratorem uestrum, quandocumque uolueritis et aprehensa retinere, constituentes uos/ in hijs dominum ut in rem uestram propriam ad faciendum inde uestre libitum uoluntatis/. Retinentes tamen Nobis et nostris quod si dictus Petrus Lupi Dargomedo uel alij predicti/ quid dictas domos et hereditamenta tenebant, facienbant uel facere tenebantur/ aliquod Nobis tributum seu seruitium pro predictis, que uobis damus, quod uos et uestri faciatis/ et facere teneamini Nobis et nostris tributum seu seruitium predictum. Mandamus etc./

Datum in obsidione de Eltx, decimo kalendas Julij, anno superius predicto/ (millesimo ducentesimo nonagesimo Sexto).

Petrus Martini mandato Bernardi de Serriano/.

\section{XVI}

1296, junio 22. Sitio de Elche.

Jaime II ordena a su Consejero Real, Bernat de Sarriá, que redacte la escritura pública de las donaciones efectuadas anteriormente a Gennoro, pues es su deseo hacer redactar un elenco de todas las donaciones realizadas por él en el Reino de Murcia y de la forma y modo en que fueron entregados 
tales bienes, con sus escrituras correspondientes (A.C.A., Reg. 340, fol. 183v).

Cum dominus Rex intendat ordinare aliquid in donationibus factis et faciendis per eum/ in Regno Murcia, et in donationibus ipsis formam et modum terrarum ponere, et Bernardo de Serriano/ dixerit et expresse (... $i$ in dicto Regno?) mandauerit quod instrumentum factum Gennoro de predictis domibus/ et hereditamentis contentis in instrumento predicto, tradatur in continenti dicto Gennoroso, saluo quod jdem/ tamen teneatur facere et implere ea que dominus Rex ratione predicte donationis ordinauerit/ dictum Gennorum ei facere pro dicta donatione. Predicttum instrumentum sub conditione predicta fuit predicto/ Gennoroso traditum, qui enim, ante traditionem predicti instrumenti, uoluit et concessit/ et etiam promissit facere et adimplere omnia que dominus Rex ordinauerit et dixerit/ quod dictum Gennorosium ratione donationis sibi facte de rebus in dicto instrumento contentis/ fore faciendum/.

Datum ut supra/ (Sitio de Eltx, decimo kalendas julij, anno domini millesimo ducentesimo nonagesimo Sexto) (1).

\section{XVII}

1296, junio 29. Sitio de Elche.

Carta de Jaime II al bayle general del Reino de Murcia, Bernat Colomer, para urgirle que a la brevedad mayor posible le haga llegar la relación de los castellanos que, transcurrido el plazo de los treinta dias otorgados para su sumisión, no han querido aceptarlo como a su nuevo soberano y señor na-

(1) Se trata de proveer de la escritura correspondiente a Gennoro o Generoso del documento precedente, de las casas $y$ heredamientos agrícolas, de regadio $y$ de secano, que le otorgara Jaime II en la ciudad y término de Murcia, en agrade. cimiento a los numerosos servicios prestados. 
tural, asi en la ciudad de Murcia como en la villa de Orihuela, para proceder al embargo y confiscación de sus bienes, para cuyo fin habrá de indicarle en la relación requerida los bienes que cada uno posee, su ubicación exacta y condición de franquicia, censual o tributaria de los mismos, por su actitud de rebeldia (A.C.A., Reg. 340, fol. 182v-183r).

Fideli suo Bernardo Colometi, bajulo Regni nostri Murcie generali uel eius locumtenenti. Cum terminus XXX dierum per Nos datus/ et assignatus omnibus illis et singulis Regni nostri Murcie, qui Nos pro domino et Rege Murcie non recognouerunt, sit elapsus et per se uel per procuratores suos per dictum tempus non comparuerint coram Nobis et propterea rebelles reputentur et loca eorum sint nostro dominio confiscata et Nos de hereditamentis seu locis/ que rebelles predicti habebant, tam in ciuitate Murcie quam in uilla de Oriola et terminis eorum, quam in locis alijs dicti Regni, uolumus plenarie informarj. Jdcirco uolumus ac uobis dicimus et mandamus firmiter et expresse quatenus de hereditamentis et bonis predictorum rebellium utcumque in dicta/ ciuitate Murcie et uilla Oriole et locis aliis dicti Regni fuerint curetis medijs omnibus quibus poteritis informare, scribendo ea et nomina illorum/ quorum fuerint et loca in quibus sita sunt, et si fuerint francha, uel si fuerint inde seruitia aliqua censualia uel tributamin, in quodam quaterno partitionum et/ cum distintione, quod quaternum Nobis in continenti mittere tenetis, sub uestri sigilli munimine interclusum. Sic in predictis inueniri quod (... borrado ¿quod in eo nullum?) aliud/ deinde inueniri possit quam illud quod inde uos in quaterno debueritis (... fieri?)/ rescribenrum/.

Datum in obsidione de Elch ut supra/ (Sitio de Elch, XXIX dias andados del mes de Junio, ayno de nuestro seynor de mil CC XC e Seys)/. Petrus Martini mandato regio/ (1).

(1) Frente a la benignidad con que actuó Jaime II con cuantos lo acataron como a su propio soberano y señor, hay que destacar la dureza e inflexibilidad con que procedió contra los rebeldes, urgiendo a sus altos funcionarios, tras el 


\section{XVIII}

1296, julio 3. Sitio de Elche.

Carta de Jaime II al Justicia de Murcia, Pedro Jiménez de Spilonga, para ordenarle que se sirva de los fueros otorgados a la ciudad por Alfonso $X$ el Sabio, mientras se lleva a cabo la compilación del fuero de Murcia, como él tiene mandado, $y$ que donde no basten aquellos, se ajusten a los de Valencia, hasta que sancione él los suyos propios (A.C.A., Reg. 340, folio 191v).

Petro Eximeni de Spilonga, Justicie Murcie uel eius locum tenenti etc. Mandamus et dicimus uobis quatenus, donec sompilatio/ qui fieri debet de Foro Murcie, per Nos uniuersitati ciuitatis Murcie concesso, utamini Foro quo utebamini tempore/ Jllustris dompni Alffonsi, quodam Regis Castelle, predecessoris nostri in Regno Murcie supradicto, et in eo in/ quo dictus forus non sufficerit, utamini Foro Valencie, donec dicta Compilatio dicti Fori Murcie facta fuerit/ ut est dictum. Datum in obsidione Eltxij, quinto nonas julij anno domini millesimo ducentesimo nonagesimo Sexto/.

\section{XIX}

1296, julio 3. Sitio de Elche.

Carta de Jaime II al jurisperito murciano, Martín de Dios, y a Juan Meeyani, en la que les encomienda la Compilación de los fueros de la ciudad de Murcia, rogándoles que lo lleven a cabo con la mayor celeridad posible, de suerte que la tengan

plazo del mes otorgado para someterse, el envío de una relación escrita y secreta, con los nombres de los rebeldes y descripción detallada de los bienes que poseian, para iniciar la confiscación de los mismos. 
concluida en fecha próxima, al objeto de que en su inminente viaje a Murcia, pueda puntualizar sobre la misma lo que estime oportuno (A.C.A., Reg. 340, fol. 191v).

Fidelibus suis Martino Dei, jurisperito Ciuitatis Murcie et Johanni Meeyani etc. Mandamus et dicimus uobis quatenus in Compilationes per uos facienda de Foro per Nos concesso probis hominibus et uniuersitati/ Ciuitatis Murcie caute et diligentissime (roto: protinus?) ut celerius poteritis procedatis. Taliter faciendo quod cum/ Nos ad dictam Ciuitatem accesserimus, dicta Recapitulatio sit perfecta et Nos super ea possimus facere/ quod facere haberemus/.

Datum ut supra/ (In obsidione Eltxij, quinto nonas julij anno domini millesimo ducentesimo nonagesimo Sexto) (1).

\section{$\mathrm{xx}$}

1296, julio 11. Sitio de Elche.

Provisión real de Jaime II a favor de la ciudad de Cartagena, recién conquistada, para confirmarle la posesion de casas, heredades $y$ de más bienes, que le donaran particularmente Alfonso $X$ el Sabio y otros reyes de Castilla, sucesores suyos, dejando a salvo siempre el derecho de terceros. Les faculta asimismo a redactar las escrituras y demás instrumentos públicos en lengua vulgar, al objeto de que todos sus vecinos puedan enterarse mejor de su contenido (A.C.A., Reg. 340, folio 283v).

(1) Por carta posterior del 25 de octubre de 1297 sabemos que intervinieron en la compilación de los fueros de Murcia, a más de los citados, el canónigo de Lérida, Raymundo Cabrera, ordenando los citados fueros, leyes y demás constitu. clones referentes a la ciudad de Murcia en un volumen, dividido en cuatro libros: ain hoc volumen per quatuor libros divisum», v. Carta correspondiente. 
Nouerint uniuersi etc. Prosequentes uos fideles nostros homines Ciuitatis Cartagenensis et eius terminorum gratijs/ et favore, ad humilem supplicationem Nobis pro parte uestra factam, confirmamus omnes donationes uobis et unicuique uestrum/factas, in generali seu speciali per Reges Castelle predecessores nostros in Regno nostro Murcie de quibuscumque/ domibus, hereditatibus seu possessionibus, prout quilibet uestrum est inde in corporali possessione, necnon/ diuisionem inter uos factam de domibus, hereditatibus seu possesionibus antedictis, per quoscumque, jure tamen cuiuslibet/ alterius semper saluo, de quo quilibet teneatur cognitionem facere ut debuerit justicie complementum. Et insuper/ concedimus uobis quod omnia instrumenta et alie scripture publice conficiantur et fiant uulgariter in predicta Ciuitate/ de Cartagenia et terminis eius. Mandantes uniuersis officialibus et subditis nostris, quod presentes confirmatio/ nem et concessionem nostras firmas habeant et obseruent et non contraueniant nec aliquem contra uenire permittant aliqua/ ratione.

Datum in obsidione Elchij, quinto Jdus Julij, anno domini millesimo ducentesimo nonagesimo Sexto/ (1).

\section{XXI}

1296, julio 15. Huerta de Lorca.

Provisión real de Jaime II al municipio de Cartagena, en la que confirma a todos sus vecinos, tanto cristianos, como sarracenos $y$ judios, los fueros y franquicias de que disfrutaran ya desde tiempos pasados, bajo la hegemonia castellana otorgados por Fernando III, Alfonso $X$ el Sabio y sus sucesores,

(1) Una vez más, se cuida Jaime II de complacer a los moradores de la ciudad de Cartagena, recién llegados a su soberanía confirmándoles las donaciones de que fueron objeto bajo la hegemonía de Castilla, seguro de ganarlos por este ca. mino más fácilmente a su obediencia y sumisión. 
de suerte que los tengan todos como emanados por él mismo. (A.C.A., Reg. 340, fol. 240v.-241r).

Nouerint uniuersi quod Nos Jacobus etc. ad humilem supplicationem per uos fideles nostros homines Ciuitatis Cartaginensis et terminorum eius/ Nobis factam, per Nos et nostros confirmamus, etiam damus et concedimus uobis predictis hominibus dicte Ciuitatis Cartaginensis et terminorum suorum/, christianis et judeis et sarracenis et uestris perpetuo omnia priuilegia, franquitates, libertates, donationes, mercedes, bonos usus et consuetu/ dines, quos et que habiustis et habetis ab illustrissimis Regibus Castelle et Murcie, uidelicet dompno Ferrando et dompno Alfonso bone/ memorie et alijs Regibus predessoribus nostris in Regno Murcie predicto usque ad tempora hodierna. Hanc autem confirmationem, dona/ tionem facimus et concessionem uobis et uestris perpetuo, sicut melius sanius et utilius dici et intelligi potest ad uestrum uestrorumque saluamentum/ et bonum intellectum. Jta quod predictis uestris priuilegijs, franquitatibus, libertatibus, donationibus, mercedibus, bonis usibus, consuetudinibus/ utamini uos et uestri, secundum quod melius ipsis hactenus usi estis, mandantes procuratoribus, bajulis, justicijs et uniuersis/ alijs officialibus et subditis nostris, presentibus et futuris, quod predicta omnia et singula firma habeant et obseruent et faciant/ inuiolabiliter obseruarj et non contra ueniant nec aliquem contra uenire permittant aliqua ratione/.

Datum in Orta Lorche, Jdibus (borrado) Julij, anno domini millesimo ducentesimo nonagesimo Sexto/.

Signum (signo real) Jacobi dei gratia Regis Aragonum etc./

Testes sunt Jacobus de Xerica, Sancius de Antilione/

Guillelmus de Angleraria, Poncius de Ribellis/

Raymundus Fulchonis, vicecomes Cardone/. 


\section{XXII}

1296, agosto 2. Murcia.

Provisión de Jaime II a favor de la villa de Mula, declarando a todos sus vecinos francos de lezda y peaje por todas las tierras del Reino de Murcia, al par que les confirma todos sus privilegios, franquicias y fueros de que disfrutaban hasta la fecha (A.C.A., Reg. 340, fol. 280r).

Nouerint uniuersi quod Nos Jacobus etc. Uolentes uos uniuersos et singulos homines Ville de Mula et terminorum eiusdem gratijs/ ac beneficijs prosequi ac fauore per Nos et omnes successores nostros, enfranchimus et franchos ac liberos facimus et inmunes/ uos uniuersos et singulos homines per omnia Regna nostra/ et loca alia terrarum et dominationis nostre, tam per terram quam per mare, quam quamlibet aquam dulcem, ab omni leçda, pedagio, passatico/, portatico et ab omni ribatico, penso et mensuratico, tam bladi quam uini et salis, quam alterius cuiuslibet mercature, quas/ uendatis aliquantocius uel ematis, recipientes uos omnes et singulos nuntios et capitularios uestros et res uestras ueniendo/, stando et exeundo per uniuersa et singula Regna et loca quecunque terrarum et dominationis nostre, sub nostra custodia, protectione/ et guidatico speciali, statuto regio precipientes firmiter et disctricte quod aliquis uicarius, baiulus, leçdarius, pedagiarius/, portarius tagie (? borrado) ponderalis uel mensurarie aut aliquis noster officialis/ uel subditus presens siue futurus non audeant/ neque possint unquam exigere uel accipere a uobis uel mercibus aut rebus uestris predictas uel aliquid de predictis nec uos seu bona/ uestra ratione predictorum distorquere uel compellere ullo modo. Mandantes firmiter et districte omnibus supradictis et singulis nostris subditis uniuersis tam presentibus quam futuris, quod hanc franchitatem nostram ratam ac firmam habeant et obseruent/ et faciant semper ab omnibus firmiter obseruarj et non contra ueniant nec aliquem contra uenire permittant aliqua/ ratione. 
Datum in Ciuitate Murcie, quarto nonas augusti, anno domini millesimo ducentesimo nonagesimo Sexto/.

Signum (signo real) Jacobi dei gratia Regis Aragonum etc./

Testes sunt Atho de Focibus/, Raymundus Fulchonis, vicecomes Cardone/.

Guillelmus de Angleraria/.

Fuit clausum per Guillelmum de Solanis/.

1296, agosto 2. Murcia.

\section{XXIII}

Jaime II confirma a los vecinos de Mula, tanto cristianos, como sarracenos y judios, los privilegios, donaciones, buenos usos, y costumbres que los reyes de Castilla y particularmen. te Fernando III y su hijo Alfonso $X$ el Sabio, le habia otorgado hasta la fecha, ratificándolos de nuevo $e$ imponiendo a todos sus oficiales la observancia y respeto de los mismos, sin la menor discriminación por etnia o religión. (A.C.A., Reg. 340 , folio 280v).

Nouerint uniuersi etc. quod Nos ad humilem supplicationem per uos fideles nostros homines de Mula et terminorum eius/ factam, per Nos et nostros confirmamus ac etiam damus et concedimus uobis predictis hominibus Mule et terminorum suorum Cristianis/, judeis et sarracenis et uestris perpetuo omnia priuilegia et franquitates, libertates, donationes, mercedes, bonos usus et/ consuetudines quos et que habuistis et habetis ab illustrissimis Regibus Castelle et Murcie, uidelicet domino Ferrando et dopmno Alffonso bone memorie et alijs regibus predecessoribus nostris in Regno Murcie et usque ad/ tempora hodierna. Hanc autem confirmationem, donationem, concessionem facimus uobis et uestris 
perpetuo sicut melius et sanius/ et utilius dici et intelligi potest, ad uestrum uestrorumque saluamentum et bonum intellectum, jta quod predictis uestris/ priuilegijs, franquitatibus, libertatibus, donationibus, mercedibus, bonis usibus et consuetudinibus utaminj uos/ et uestri secundum quod melius hactenus usi estis. Mandantes procuratoribus, baiulis, justicie et uniuersis alijs/ officialibus et subditis nostris presentibus et futuris quod predicta omnia et singula firma habeant et obseruent et/ faciant inuiolabiliter obseruarj et non contraueniant nec aliquem contrauenire permitant aliqua ratione./

Datum in Ciuitate Murcie, quarto nonas augusti anno predicto/ (millesimo ducentesimo nonagesimo sexto).

Signum (signo real) Jacobi dei gratia Regis Aragonum etc./

Testes sunt Atho de Focibus/ Raymundus Fulchonis, vicecomes Cardone, Guillelmus de Amgleraria/. Fuit clausum per Guillelmum de Solanis/ (1).

\section{XXIV}

1296, agosto 3. Murcia.

Carta de Jaime II al Comendador santiagusta de Caravaca, Cehegin y Bullas, fray López Pays, ordenándole la inmediata restitución de ciertos bienes retenidos por la Orden de Santiago en los lugares referidos a los judios Yuzeff y Abolazar, hermanos, con todas las cantidades pecuniarias que les adeu-

(1) Con esta provisión real a favor por un igual para cristianos que sarracenos y judios, completa Jaime II la serie de fueros y exenciones otorgados a los vecinos de Mula en el privilegio anterior, sin establecer la menor discriminación por credo o raza, igual que lo hiciera, 15 días antes, desde la huerta de Lorca (15 julio 1296) con otro privilegio similar a favor de la ciudad de Cartagena. 
dan, pues no está dispuesto a tolerar que se les haga injuria o mal alguno como a vecinos de Mula (A.C.A., Reg. 340, fol. 276r).

Al amado Fray Lopes Pays, Comendador de Carauaca et de Cehegin e de Bullas, sepades que Juceff e Abolaçarj, hermanos judios de Mula, uinieron ante Nos e/ dixeron Nos que algunos bienes les eren tenidos en los dichos logares de la Horden, en algunas quantidades, de manera porque nos clamaron mercet que uos embiassemos rogar que los/ fiçiessedes pagar los ditxos deudos. E Nos, la lur supplication recebuda, rogamos/ e deçimos uos que constringades o fagades los restituyr todos aquellos/ e lures bienes, que serien deudos obligados a los dichos judios a pagar a ellos sin tarda e complidament de dreyto. Otrossi uos rogamos que a los dichos judios/ e a lures coses no lexedes fer tuerto ni fuerça, ante los mantengades/ en lur dreyto.

Dada ut supra/ (en Murcia, tertio nonas augusti, anno domini millesimo ducentesimo nonagesimo Sexto) (1).

\section{XXV}

1296, agosto 3. Murcia.

Carta de Jaime II al alguacil y alcaydes de Mula para urgirles la pronta restitución de las cantidades que les adeudan cier. tos vecinos de aquella villa a los judíos Moisés Yuzeff y Albolazat, hermanos $y$ vecinos de Mula, a quienes se resisten a amortizar las deudas contraidas (A.C.A., Reg. 340, fol. 276r).

(1) Una vez más aparece ampliamente documentada la actitud benevolente de Jaime II hacia los judíos y sarracenos, impidiendo tajantemente la menor discriminación con los mismos, por motivos de religión o de raza, impelido a ello, sin duda, por constituir éstos la mayoría poblacional del Reino de Murcia, cuya conquista quería asegurar por todos los medios. También es digno de nota el número crecido de valencianismos empleados en la redacción de esta carta en castellano. 
Alguaçilo et alcaydis de Mula. Ex parte Mosse Yuçeff et Albulcaçati filiorum judeorum Mule, fuit expositum coram Nobis, quod aliqui in uilla et termino de Mula conmorantes, quos/ dam judeos sunt in debitis ut dicitur obligati, ipsa debita eisdem maliciose/ soluere contradicunt. Quare mandamus uobis quatenus si est ita, omnes illos et eorum bona/ quos inueneritis esse dictis judeis in debitis obligatos, cohercitione debita et prout/ faciendum fuerit compellatis ad soluendum ipsis judeis debita predicta uel ad faciendum/ etc./

Datum Murcie, tertio nonas augusti, anno domini millesimo ducentesimo nonagesimo Sexto/ (1).

\section{XXVI}

1296, agosto 8. Játiva.

Carta de Jaime II al alcayde de Cartagena o a su lugarteniente para prohibirles que graven en modo alguno fiscalmente a los vecinos de la ciudad, contra sus fueros y costumbres, confirmados por él con anterioridad (A.C.A., Reg. 340, fol. 285v).

Fideli suo alcaydo Cartagenie uel eius locum tenenti intelleximus quod uos aliquando grauatis homines/ dicti loci de Cartagenia, contra consuetudines et priuilegia per Nos confirmata et per eos actenus/ usitata. Quare uobis dicimus et mandamus, quatenus dictos homines, juxta predictas eorum consuetudines seu/ priuilegia per Nos confirmata, non grauetis seu grauarj ab aliquo permittatis/.

(1) Se trata de los mismos dos hermanos judios y vecinos de Mula, Moysés Yuzeff y Albolazar, del documento siguiente, que tras haber efectuado repetidos préstamos a otros vecinos, ahora se veían privados de su devolución, lesionando gravemente sus intereses legftimos, contra lo que reacciona justamente Jaime II ordenando a los alcaydes y alguacil de la villa que impongan a los dudores referidos cuanto antes la debida restitución, desechando contundente toda posible discriminación racial o confesional. 
Datum Xatiue ut supra/ (anno domini millesimo ducentesimo nonagesimo Sexto) (1).

\section{XXVII}

1297, octubre 25. Tarragona.

Carta de Jaime II a los nobles y fieles súbditos de la ciudad y Reino de Murcia para notificarles que con aquella fecha sancionaba los Fueros compilados por el canónigo leridano, Raymundo Cabrera y otros llos citados sin duda en las cartas del 3 de julio de 1296, Martin de Dios y Juan Meeyani, jurisperitos), recopilados en un volumen, que constaba de cuatro libros, y que se sirvieran exclusivamente de ellos por disposición regia suya, bajo severas penas corporales a los infractores, y que guardasen el original en Murcia, facilitando copia del mismo a los restantes lugares del Reino, para su fiel cumplimiento (A.C.A., Reg. 253, fol. 4r). Publ.: Torres Fontes, J., «Colección de documentos para la historia del Reino de Murcia» (CODOM), II Documentos del siglo XIII, Murcia, 1969. doc. CXXVI, p. 130.

Nobilibus et dilectis ac fidelibus uniuersis et singulis tam in civitate quam in regno Murcie constitutis, salutem et gratiam. Pridie, dum eramus in regno nostro Murcie personaliter constituti, ad humilem supplicationem et magnam instantiam fidelium nostrorum proborum hominum civitatis Murcie et aliarum regni predicti, diversos foros diversasque leges seu constitutiones in diversa dispersos volumina ad magnam

(1) Atento Jaime II a congraciarse con los nuevos súbditos del Reino de Murcia, en vías todavía de conquista y sumisión en su parte meridional por aquellas fechas, no dudó en confirmarles todos sus privilegios y franquicias, obtenidos bajo su anterior dominación castellana, por Alfonso $X$ el Sabio, de modo particular, $y$ sus sucesores, hasta Fernando IV, velando celosamente por su fiel mantenimiento y ejecución. 
et evidentem utilitatem totius regni predicti per discretos et prudentes Raymundum Caprarii, canonicum Ilerdensem et (... en este espacio situamos nosotros los autores citados en el Regesto) quos ad hec specialiter deputavimus in hoc volumen per quatuor libros divisum quod forum Murcie volumus nominari, resecatis quibusdam superfluis, providimus redigendos, adicientes aliquot per que nonnulla, que in prioribus erant dubia declarantur. Volentes autem ut universi et singuli, tam civitatis quam regni predicti, tam in judicio quam extra, compilatione hac utantur; precipimus sub pena corporis et bonorum quod nullus aliis foris uti presumat nec aliquam compilationem facere absque nostra auctoritate regia speciali. Quod volumen vobis sub sigilli nostri munimine mittimus interclusum, et volentes et mandantes quod volumen ipsum pro originali apud civitatem Murcie remanente universis regni predicti detur et tribuatur copia de eodem.

Datum Terrachone, octavo kalendas novembris (1).

\section{XXVIII}

1298, febrero 9. Sitio Castillo de Alhama.

Provisión de Jaime II a favor de los judios de la villa de Alicante, que, por motivos de ocuparse en faenas agricolas, como la siega y corta de árboles, se desplazaban a aquel lugar en busca de trabajo, para que disfruten de los mismos fueros $y$ franquezas que los restantes vecinos de la villa (A.C.A., Canc. Reg. Grat. 195, fol. 120 r.)

Judeorum de Alacant/

(1) A partir de la fecha indicada no habrá otro Fuero para la ciudad y Reino de Murcia que éste sancionado formalmente por Jaime II, y se servirán de él en exclusiva, tanto dentro como fuera de los tribunales, bajo las más estrictas penas corporales y sanciones fiscales o calonias. 
Noverint uniuersi quod Nos Jacobus Rex etc. Volentes uos uniuersos Judens, habitatores de Alacant, speciali prosequi gratia et favore/ per Nos et nostros presentes et futuros, damus et concedimus predictis Ju. deis siccatoribus de Alacant, presentibus et futuris et/ universis etiam qui extra Regnum nostrum ad locum ipsum de Alacant, causa siccandi ibi peruenerint, quod habeatis omnes/ franquitates quas habent vicini loci predicti de Alacant. Mandantes per presentem cartam nostram procuratoribus, Justicijs/, lezdarijs et pedagiarijs et uniuersis alijs officialibus nostris presentibus et futuris quod, promitentes uos uti franquitatibus/ predictis, prout vicini de Alacant utuntur ex ipsis, huiusmodi donationem et concessionem nostram teneant et obseruent et non/ contraueniant nec aliquem contrauenire permitant aliqua ratione. In cuius rei testimonium presentem cartam nostram fieri jussimus/ et nostro sigillo apendicio sigillari./

Datum in Alacant, quinto Jdus Septembris, Anno domini millesimo ducentesimo nonagesimo septimo/

Guillelmus de Solanis mandato regio facto in obsidione/Castri de Alhama/ (1).

\section{XXIX}

1301, enero 21. Valencia.

Fuero a favor de los vecinos de Orihuela para que puedan comerciar por donde quieran, dentro y fuera de la Corona, con aquellos productos $y$ mercancías que, de ordinario no se

(1) Queremos subrayar aquí el singular interés de este monarca por estimular a la población judía de estas tierras a afincarse en ellas, facilitándoles el disfrute pleno de los fueros y franquezas, de que gozaban los restantes vecinos cristianos, urgiendo a sus funcionarios públicos el estricto cumplimiento de sus disposiciones legales de favor, por redundar todo ello en asegurar la explotación agrícola-ganadera y demás producción en beneficio de toda la sociedad y de la Corona. 
podían sacar del Reino y estaban clasificados entre las coses vedades y prohibida por ello su exportación. Eran éstos, en. tre otros: la pez, sebo, alquitrán, lino, cañamo, jarcias, hierro, armas, caballos, granos, viandas, etc. Se reservaba Jaime II la facultad de levantar la franqueza otorgada y poner el veto a sacarlos de sus tierras, en tiempos de carestía en el Reino de Valencia, renovando una vez más su prohibición permanente de poner tales cosas en manos del enemigo o de los sarracenos (A.M. Orihuela, Lib. de Priv., 2588, fol. 55v-56r; A.H.N., Priuilegia, 1368 B, fol. 100v).

... Jtem establim et atorgam que tot hom de qualque condiçio sie del Regne pusque portar et tramestre blat et vianda et totes altres coses et mercaderies on se volrra, exceptat a terra de enmichs del senyor Rey ab qui gueregats o de sarrahins. Exceptat que nengu no pust ha trer fora la terra nostra aquestes coses vedades, ço es a saber: peguntta, seu, alquitra, fusta, canem, fil de xarcia, fferre et armes et cauaylls. Retenim empero que per necessitat de carestia del Regne de Valentia nos pustam possar vet en la terra del blat et de la vianda et deles altres coses. Mas quen pugan fer graçia a qujns volrren, axi empero que quela graçia no sia feita per diners. E sis fahia quel vet del blat et de les altres viandes que serien vedades per nos fos absolt quant a aquella uegada. Et que nengun oficial nostre daço no deia pendre dineres ne fer nenguna frau et siu faia que nos lom punissem en altra manera quel vet fos absolt quant a aquella uegada... (1).

(1) Faltan en la reproducción que hace el Infante D. Fernando de este privilegio de su abuelo, Jaime II, el protocolo y escatocolo correspondiente, que significamos con los puntos suspensivos. 